821.163.41.09 Милићевић, Вељко https://doi.org/10.18485/msc.2017.46.2.ch38

Адријана М. МАРЧЕТИЋ* Универзитет у Београду Филолошки факултет
Оригинални научни рад

Примљен: 01. 10. 2016.

Прихваћен: 10. 02. 2017.

\title{
НАРАТИВНЕ ТЕХНИКЕ У ПРОЗИ ВЕЉКА МИЛИЋЕВИЋА**
}

\begin{abstract}
Српска критика још увек није открила шта све чини иновативност, посебност и вредност прозе Вељка Милићевића, а посебно Беспућа (1906), његовог најбољег дела. Овај Милићевићев кратки роман најављивао је приповедне поступке и теме који ће се у нашој књижевности, али и у другим европским књижевностима, систематски развијати тек по свршетку Првог светског рата. Насупрот социјално-сеоској тематици која је доминирала у прози српских приповедача с краја 19. века, Милићевић у средиште пажње поставља унутрашњи живот својих јунака и јунакиња. Нова психолошка тематика захтевала је и нове приповедне технике, какве у старијој српској књижевности нису биле систематски примењиване. Милићевић је у ту сврху посегнуо за психонаративним техникама, доживљеним говором и фокализованим описима, инспиришући се Флобером и Мопасановом прозом. Али, пошто је несумњиво био оригиналан и самосвојан таленат, Милићевић није само копирао своје узоре већ је приповедне технике француског натуралистичког романа развијао самостално, користећи посебне могућности српског језика, и дајући им свој лични печат.
\end{abstract}

Кључне речи: Вељко Милићевић, Беспуће, српска проза, доживљени говор, технике описивања

На самом почетку 20. века Вељко Милићевић је био једна од највећих нада српске књижевности. Свој први рад штампао је као петнаестогодишњак (1901), а само две године касније, објавивши приповетку „Мртви живот” (1903) у Српском књижевном гласнику, постао је, по Скерлићевим речима, „најмлађи сарадник којега је овај часопис икада имао” и писац на чији се „леп и приметан таленат у рађању” озбиљно рачунало (Скерлић 1964: V, 172). И две следеће Милићевићеве приче, „Вихор” (1904) и „Млаке душе” (1905), такође објављене у $C K Г$, наишле су на врло афирмативан пријем код критичара, али највише пажње - потпуно заслужено - привукао је његов први ро-

*amarcetic@fil.bg.ac.rs

** Рад је настао у оквиру пројекта ИКУМ 178008 који финансира Министарство просвете, науке и технолошког развоја Републике Србије. 
ман Беспуће, који је у СКГ објављиван у наставцима, од јануара до јуна 1906. године, а у посебној књизи изашао је тек шест година касније, 1912. године.

Млади писац је врло брзо постао један од најистакнутијих представника новог нараштаја у српској књижевности на самом почетку 20. века, а његов роман, већ и по свом наслову, „карактеристично дело” овог доба. Скерлић је с правом приметио да је Милићевићева проза изражавала једну потпуно нову врсту сензибилитета, својствену младим песницима и прозаистима који су тек ступали на књижевну сцену, Борисаву Станковићу, Вељку Петровићу, Иви Ћипику, Петру Кочићу. Све њих одликује „способност за посматрање и јака осетљивост; много природности и много особености"; по ономе што виде око себе, ови писци су „натуралисти [...] а идеалисти по ономе што осећају у себи; цела њихова уметност је натуралистичка, носталгична, лична, сензуална и социјална" (Скерлић 1964: V, 172).

Период између 1903. и 1906. био је најплоднији у Милићевићевој краткој каријери. Између „Мртвог живота” и Беспућа, објавио је и „Вихор”, „Млаке душе” и „Мутну причу”, сарађивао је у сарајевској Нади, и у загребачким часописима Савременику и Нашој снази. Али, 1906, када је изашао и последњи наставак Бесnућа, и када су сви очекивали да ће млади писац наставити да гради успешну књижевну каријеру, Милићевић је практично престао да пише и објављује. Осим понеке приче, Милићевић је за живота објавио још само роман Опсене (1922), који по квалитету ни издалека није успео да се приближи првом, младалачком роману. ${ }^{1}$ Драгиша Витошевић, један од најбољих познавалаца Милићевићевог дела међу каснијим српским књижевним историчарима, каже да Милићевићу више никад није пошло за руком да понови „подвиг” који је извео са Беспућем (Витошевић 1982: 97). ${ }^{2}$

Чак и данас Беспуће изненађује својом модерношћу, књижевном самосвешћу и, можда највише, лепотом и зрелошћу прозног стила какве би читалац пре очекивао од неког врло искусног приповедача него од тек свршеног гимназијалца који се налази на самом почетку романсијерске каријере. Овај „мали роман”, како на плану тематике, тако и на плану приповедне технике, ишао је испред свог времена и најављивао приповедне поступке и теме који ће се у нашој књижевности, али и у другим европским књижевностима, систематски развијати тек по свршетку Првог светског рата. Милићевићево Беспуће и његове ране приповетке већ на самом почетку века најављују прозу какву код нас после 1918. пишу Милош Црњански, Иво Андрић, Драгиша Васић и Растко Петровић.

Већ три ране Милићевићеве приче, „Мртви живот”, „Вихор” и „Млаке душе”, у већој или мањој мери, уводе у српску прозу једну нову тему и једну нову технику. Насупрот социјално-сеоској тематици која је доминирала у прози претходне генерације приповедача, Милићевић тежиште свог при-

\footnotetext{
${ }^{1}$ Посмртно, у Српској књижевној задрузи објављене су му две збирке приповедака, 1930. и 1939, које је приредио Живко Милићевић.

${ }^{2}$ Витошевић је Нолитову едицију Педесет српских романа критички приредио Беспуће, узимајући као основу издање самог писца (Сарајево, 1912), и ми цитирамо роман према овом издању.
} 
поведања ставља на психолошку тематику, и у средиште пажње поставља унутрашњи живот својих јунака и јунакиња. Наравно, психологија је у српској прози била присутна и раније, али по правилу у вези са социјалним статусом јунака и истим таквим преокупацијама самих писаца. Код Милићевића, међутим, психологија има вредност по себи, она је потпуно самостална и сама по себи легитимна област интересовања, што писцу омогућује да је истражује и предочава слободно, независно од било каквих социјалних стереотипова формираних у ранијој књижевности. Тиме не желимо да кажемо да је социјална тематика Милићевићу била сасвим страна; он доноси галерију изузетно успелих портрета типичних карактера свог родног краја, Лике, сељака, али и сеоске „господе”, чиновника и свештеника, који су махом представљени у негативном светлу. Али, иако у призорима из живота народа, писац наступа социјално ангажовано, овај ангажман, као и социјална тематика у Милићевићевој прози уопште, представља ипак само мање или више рељефно истакнуту позадину, на којој се одвија главна, психолошка драма јунака.

И у Бесnyћy, фокус приповедања је на психолошком доживљају јунака, и то у једном посебном смислу. Аутобиографски јунак овог романа, Гавре Ђаковић, непрестано се самопреиспитује, настоји да открије ко је и чему тежи, док писац настоји да нам дочара управо сам тај процес у свим његовим појединостима. Сви остали елементи, укључујући ту и сликање социјалног амбијента, стављени су у функцију приповедања о том доживљају. У погледу „дубине” психолошке анализе Милићевић је отишао корак даље од других српских прозаиста. У предочавању Ђаковићеве психологије нема ничег стереотипног; Гавре Ђаковић је тип за себе, нови карактер у српској прози, човек који је изгубио животни смисао, али не зато што се, на пример, разочарао у љубави, већ без икаквог видљивог разлога, сасвим изненада и неочекивано. У Ђаковићевом случају, губитак животног смисла није мотивисан никаквим спољашњим околностима, па можемо само да нагађамо када је и због чега код њега „умрла воља за све”. Али, управо овај недостатак спољашње мотивације чини га модерним књижевним јунаком, „егзистенцијалистом”, блиским сензибилитету савременог читаоца.

Нову тему у Милићевићевој прози пратила је и једна нова приповедна техника, коју ћемо за ову прилику назвати „објективним” приповедањем у трећем лицу. То је приповедање из којег су уклоњени очигледни знаци приповедачевог присуства, дигресије, екстензивни коментари и обраћања читаоцу, а збивања су предочена „објективно”, на драмски начин, из перспективе неког од јунака, без пишчевог уплитања. У класичним западноевропским романима, на пример, код Флобера и Золе, „објективни” начин приповедања по правилу је удружен с једном од најважнијих психонаративних техника - с доживљеним говором (erlebte Rede) или слободним индиректним стилом (le style indirect libre). Такав је случај и код Вељка Милићевића. У његовим причама и романима, од „Мртвог живота” до Опсена, слободни индиректни стил, у контексту „објективног” приповедања у трећем лицу, представља доминантну наративну норму. Наравно, и код ранијих српских приповедача и 
романсијера могли би се наћи примери оваквог приповедања, али тешко да има иједног пре Милићевића који је доживљени говор доследно примењивао у том обиму и на тај начин, у вези са новом тематиком, психолошким доживљајем јунака. Милићевићу је ова техника главно средство помоћу којег дочарава развој и зрење унутрашњег доживљаја јунака; експериментишући, он ју је временом усавршавао, обогаћујући на тај начин и сопствени стил и изражајне могућности српске прозе уопште.

Слободном индиректном стилу Милићевић се учио првенствено од француских писаца, Флобера и Мопасана, али та чињеница ни најмање не умањује вредност његове прозе. Штавише, задивљујуће је како је лако, природно и непретенциозно тако млад писац усвојио овај приповедни начин и с колико га је књижевног и језичког осећања применио у српском језику. За веома кратко време, од „Мртвог живота” до Бесnућа, Милићевић је постао прави мајстор ове прозне технике, а њоме се служио тако надахнуто и виртуозно да бисмо га могли назвати српским Флобером само да га је таленат мало дуже послужио и да је, после Беспућа, написао бар још један или два романа сличне инспирације. Техници доживљеног говора својствено је да евоцира јунаков језик и начин изражавања, чиме се у приповедању истиче његова психолошка перспектива. У ту сврху могу послужити различита језичка средства, глаголска времена, заменице, узвици и интерпункцијски знаци који изражавају јунаков емоционални став. Будући да је доживљени говор наративни поступак који се у великој мери ослања на особине самог језика на којем је текст написан, он увек има и неке специфичне особине које произлазе из природе тог језика. На пример, приповедање у садашњем, односно будућем времену једна је од карактеристичних особина доживљеног говора у српском језику. Све ово можемо запазити у следећим примерима, где ћемо црним истаћи речи путем којих се директно конституише доживљени говор:

Главу је поднимио у руке и наслонио се лактовима о свој сто. Гледао га је дуго. Ето, позна га у најмање ситнице, сваку резотину, сваку мрљу, црвоточину, позна на њему. Десет година свога учитељевања сједио је он ту, за својим столом. Ту су се рађале његове идеје, утопијске идеје, ту је он снивао, у сумрацима, како ће он дићи - не дићи већ ускрснути - народ, морално и материјално (Милићевић 1903: 338).

У овом одломку из „Мртвог живота” само су прве две реченице исприповедане с тачке гледишта неименованог приповедача, „објективним начином”. Остатак одломка, почевши од реченице „Ето, позна га у најмање ситнице...”, исприповедан је такође у трећем лицу, али из перспективе јунака, учитеља Дамјана Дамјановића; просторна тачка гледишта, лексика, асоцијативни оквир у целини нису приповедачеви, већ јунакови. На то упућује узвик „ето” којим почиње реченица, прилог „ту” који фокусира приповедање у просторну тачку гледишта јунака и, најзад, избор лексике којом се изражава јунакова емоционална тачка гледишта: „ту је он снивао... како ће... дићи - не дићи већ ускрснути... ”. Глагол „ускрснути”, који приповедач бира уместо неутралнијег ,дићи”, уводи читаоца у Дамјанов унутрашњи доживљај и сугерише му емоционални и морални значај који је за младог учитеља у прошлости имала идеја о просвећивању народа. Наравно, употреба овог глагола може 
се схватити и у иронијском кључу, као израз приповедачевог односа према идеализму младог учитеља, али управо таква двосмисленост јесте једна од суштинских особина доживљеног говора, у којем је често немогуће успоставити јасну разлику између приповедачеве и јунакове речи, а самим тим ни определити се за једно од могућих значења исказа.

Следећи одломак из „Вихора” прави је пример флоберовског доживљеног говора:

Немиран осјећај будио се у души Смиље Тадићеве, осјећај који она није могла испитати својим разумом, већ га је само у души појимала. Будило се у њој нешто што је она одавно слутила и очекивала да ће доћи, и то је избијало на површину тек у ноћи, топлој и мекој, страсној и разблудној. Дању рад од човјека одбија такве мисли, рад што исцрпљује снагу, и сунце што убија мозак, онда се чује само звек мотике о тврду, упечену земљу, или једнолични шум косе кад ваља оштрим сјечивом за собом ниску, мршаву, брдску траву, или кад писне коса кад запара тврд камен. А ноћ потискује такве мисли... она омамљује чељаде да заборави дневни труд и муку, она буди оно што се чинило да је успавано... (Милићевић 1904: 1203)

И овде је само прва реченица исприповедана „објективним” начином, у трећем лицу, из перспективе неименованог приповедача. Већ у другој реченици приповедач прелази на доживљени говор, предочавајући нам мисли и осећања своје јунакиње, посрнуле сеоске девојке, Смиље Тадићеве. По начину размишљања, Смиља неодољиво подсећа на Ему Бовари, а то је зато што нам је њена свест предочена на исти начин на који Флобер дочарава свест своје јунакиње. У првом одломку „У души Смиље Тадићеве” буди се „осјећај који она није могла испитати својим разумом”, јер је, као и у Емином случају, реч о јунакињи несофистициране, ограничене интелигенције: и Смиља је жена која не реагује разумом, већ чулима. За разлику од унутрашњег доживљаја Дамјана Дамјановића, у доживљају просте сеоске девојке, нема сложених, јасно артикулисаних мисли и идеја; њеном унутрашњем доживљају својствене су, баш као и Еми Бовари, чулне сензације и фантазије. Кад завири у њену свест, приповедач региструје готово искључиво чулне представе, „сунце што убија мозак”, „звек мотике о тврду, упечену земљу”, „шум косе кад ваља оштрим сјечивом брдску траву” итд., које упућују на Смиљину сензуалну, нерефлексивну природу. У причи у целини, Смиљино размишљање обично није дато у облику јасно артикулисаних мисли, већ у форми стереотипних представа које као да су преузете из неких еротско-сентименталних романа, сличних онима које је можда читала и Ема Бовари. Међутим, овде посебно треба истаћи да Смиљина свест није предочена непосредно, као у унутрашњем монологу, није дата њеним речима и једноставном репродукцијом онога што она осећа. Овде не говори Смиља, већ писац: он бира утиске, прави метафоре, стилски обликује реченице. Осећања су Смиљина, али она никад не би умела да их изрази онако како нам Милићевић о њима приповеда.

Као и у ранијим причама, и у Беспућy је доживљени говор главна техника помоћу које приповедач дочарава унутрашња преживљавања свог јунака; међутим, сада је обим тих унутрашњих преживљавања толико увећан 
да практично заузимају цео роман. Осим у шестој глави, која је накнадно дописана за издање из 1912. године, и у којој нас приповедач упознаје са предисторијом Чехиње Ирене, сва остала збивања, од прве до последње реченице, предочена су из перспективе главног јунака: у Бесnyћy, све „пролази" кроз Гавру Ђаковића. Истовремено, обим спољашњих збивања сведен је на минимум. У Беспућу уочавамо још једну важну особину Милићевићевог приповедања. Основна наративна ситуација и овде је безлично приповедање у трећем лицу; нагласак је на предочавању психолошких стања, али је значајан део текста посвећен описивању предмета и пејзажа. Међутим, описи су по правилу помешани с приповедањем о унутрашњем преживљавању јунака, односно остварују се комбиновањем дескрипције с доживљеним говором. Посматрано у целини, у Милићевићевом приповедању најбољи су управо овакви, интериоризовани описи. Његове технике описивања су разноврсне, суптилне и изнад свега модерне; Милићевић се служи фокализованим описима, итеративним описима, симболичним и метафоричним описима, осамостаљеним описима. Остављајући по страни несумњив приповедачки таленат, инспирацију за овако широк репертоар различитих дескриптивних техника Милићевић је могао да нађе само код француских писаца, тачније код Флобера: као и код Флобера, опис код Милићевића постаје психонаративна техника. Предочен из перспективе самог јунака, опис је у ствари слика јунаковог унутрашњег доживљаја, он је прожет јунаковим емоцијама и изражава његово расположење. Истовремено, опис може да сугерише и приповедачев, односно пишчев доживљај света. То је најизразитије у симболичним детаљима којима Милићевићеви описи обилују. На пример, опис којим почиње четврта глава романа може се схватити као нека врста прикривеног ауторског коментара који преноси исто осећање промашености и узалудности живота које током читавог романа прогони и самог јунака:

[...] главном улицом комешало се, мимоилазећи се, мноштво вечерњег свијета који је био изашао у своју обавезну шетњу; људи се гласно поздрављали... жене бацале погледе... средином улице пролажаше једна гомила зидарских радника пуних креча по одијелу и по изобличеним, рђавим шеширима... А кроз то мноштво, лијено и спокојно окретали се точкови на двоколним таљигама, прљавим и слупаним од дасака, пуним смећа и ђубрета, из кога је вирила једна прљава лопата... на смећу спавао је слатко млад радник, са црвеним и једрим лицем, у искрпљеном прљавом одијелу, са уздигнутим коленима и са широм опруженим рукама, са изразом задовољства на лицу: снивао је, ваљда нешто лијепо (Милићевић 1982: 45).

Већ сам по себи, опис младог радника руменог лица који слатко спава на гомили ђубрета довољно је сугестиван, а контраст на којем се заснива изражава, на флоберовски начин, фундаменталну иронију живота у којем, једно крај другог, стоје трулеж, прљавштина и смеће и, с друге стране, лепота и здравље младости. Овај опис представља увод у епизоду у којој нам је, у слободном индиректном стилу, предочено како Гавре Ђаковић размишља о смислу живота. Карактеристично је да су ту јунакове мисли „помешане” са идиличним описом Уне и сеоског пејзажа, који су такође предочени из јунакове перспективе. Лепота пејзажа наводи га на помисао да би „можда било 
боље да се није одвајао од своје земље", да би можда ту пронашао срећу и да „не би можда осјећао оволико празнине у животу” (Милићевић 1982: 47). У различитим тумачењима Милићевићевог романа ова размишљања Гавре Ђаковића, као и читава ова епизода, заузимају средишње место. Готово у целини ово место цитира и Скерлић у приказу Беспућа из 1912. То је и разумљиво будући да је ово једино место у роману на којем се читаоцу нуди некакво објашњење за туробно јунаково расположење. Али, иако је ово место са становишта тумачења романа у целини несумњиво важно, не смемо да заборавимо да је оно предочено као размишљање самог јунака, у форми доживљеног говора, па би било брзоплето закључити да јунаково размишљање подупире и приповедачево тумачење предочених збивања. У „мемли и чами” провинцијске „плитке средине”, Гавре Ђаковић се осећа „сам, одвојен од свега, као у једној страшној бескрајној пустињи без хоризонта":

Гурнули су га у школе да буде господин, одвојили су га од земље и народа, спријечили га да ухвати коријена у земљи из које је изникао, гурнули га у један живот у који кад је загледао, он се згрозио, ужаснуо, тргнуо. И пошао је натраг кад већ више мостова није било: у онај живот није се усудио да уђе, а овај други постао му је неприступан (Милићевић 1982: 48).

На основу ових редова Скерлић и неки каснији критичари закључили су да је Милићевић кроз лик свог јунака хтео да прикаже једну у оно време популарну књижевну идеју, идеју о „човеку без корена”, коју су под утицајем Мориса Бареса и његовог романа Les Déracinés, у југословенским књижевностима развијали и други писци. Драгиша Витошевић каже да је у српској критици о Милићевићевом јунаку постојала представа „скоро искључиво као о 'човеку без корена"' (Витошевић 1982: 140), али он сам није сасвим склон да Ђаковића без остатка сведе на тип „човека без корена”. Он с правом примећује да начин на који нам је овај јунак предочен није искључиво типски. Није све у „раскорењености”, каже Витошевић, ту је „и цео низ других 'одвајања"” које по њему такође морамо узети у обзир у тумачењу Ђаковићевог лика (Витошевић 1982: 142). Иако је на бољем путу од Скерлића, који је Милићевићу замерио да није понудио уверљиву анализу јунаковог друштвеног преображаја, ни Витошевићево тумачење није сасвим прихватљиво.

По спољашњој, егзистенцијалној ситуацији, Гавре Ђаковић би се заиста могао узети као пример „човека без корена”. Пореклом са села, из интелектуално сиромашне породице, он одлази на школовање у Загреб: „гурнули [су] га у један живот у који кад је загледао, он се згрозио, ужаснуо, тргнуо.” Али, видели смо да су ове речи део епизоде у којој, у форми доживљеног говора, јунак преиспитује своје осећање животне промашености; оне не морају нужно изражавати и приповедачево становиште. Штавише, када треба разјаснити зашто је у његовом јунаку „умрла воља за све”, приповедач је врло уздржан и нигде у роману изричито не каже зашто се у њему одједном све „сломило”. Милићевић у ствари уопште не обликује свог јунака као типичног „човека без корена”; Гавре Ђаковић је и нешто мање и нешто више од тога. С једне стране, њему недостају социјална амбиција и извесна морална неосетљивост које по правилу одликују типичног „раскорењеног човека”. С 
друге стране, по сензибилитету и капацитету за самоанализу, он је много сложенији и у сваком случају потпуно друкчији од типичног parvenu-а. Пре него тип, Ђаковић је индивидуалиста, јунак који трага за смислом живота, али не у друштвеним и моралним стереотиповима, већ у болном и тегобном самопреиспитивању, у сопственој души, ,у страшној бескрајној пустињи без хоризонта" (Милићевић 1982: 48).

Скерлић је замерио Вељку Милићевићу што „није успео да нам свог кукавног јунака представи као жртву једног тешког социјалног преображаја, прилагођавања једне младе расе условима модернога живота" (Скерлић 1964: V, 297), не помишљајући да овоме то можда није ни била намера и не питајући се није ли можда управо у том „промашају” била садржана највећа иновативност и вредност овог романа. Беспуће је много више психолошки роман но роман из друштвеног живота. Али, у томе не треба видети његов недостатак. Напротив, управо такав какав јесте, уроњен у танану психолошку анализу од прве до последње странице, овај роман представља сасвим оригиналну појаву у српској књижевности прве деценије 20. века. И данас он изгледа модеран и нов управо по својој радикалној посвећености психолошкој анализи и „моралној аутопсији” једног нетипичног, потпуно самосвојног јунака.

\section{ЛИТЕРАТУРА}

Витошевић 1982: Д. Витошевић, Поговор, у: В. Милићевић, Беспуће, Београд: Нолит.

Витошевић 1990: Д. Витошевић, Српски књижевни гласник 1900-1914, Београд: Институт за књижевност и уметност.

Милићевић 1903: В. Милићевић, „Мртви Живот”, Београд: Српски књижевни гласник, бр. 5 - 1. новембар, 1903 - 1. јануар 1904.

Милићевић 1930: В. Милићевић, Приповетке I и II, 1930, Београд: СКЗ.

Милићевић 1982: В. Милићевић, Беспуће, Београд: Нолит.

Милићевић 1930: Ж. Милићевић, Поговор, у: В. Милићевић, Приповетке I, Београд: СКЗ.

Скерлић 1964: Ј. Скерлић, Писци и књиге $I V$ и $V$, Београд: Просвета. 
Adrijana M. Marčetić

VELJKO MILIĆEVIĆ'S NARRATIVE TECHNIQUES

(Summary)

Serbian criticism has not yet entirely revealed the uniqueness, significance and true value of Veljko Milićević's fiction, especially of his best work, short novel Bespuće, 1906 (Wastelands). In it Milićević had announced the narrative style and topics that will, in Serbian and other European literatures, systematically be developed only after the WWI. In contrast to the fiction with social and rural topics that dominated Serbian literature of the late 19th century, Milićević puts in the spotlight the inner life of his heroes and heroines. New psychological themes required new narrative techniques. For that purpose Milićević reached to psychonarrative techniques, free indirect speech (narrated monologue) and focalized descriptions, inspired by Flaubert's and Maupassant's works. But Milićević did not just imitate his models; he independently developed his narrative style, using the special features of the Serbian language, and giving it a unique personal touch. 